\title{
Conflict-Inhibiting Norms*
}

\author{
Peter T. Leeson Christopher J. Coyne
}

Email: PLeeson@GMU.edu; CCoyne3@GMU.edu. Address: George Mason University, Department of Economics, MS 3G4, Fairfax, VA 22030. We thank Bruce Benson, Peter Boettke and the editors for helpful comments and suggestions. 


\section{Introduction}

How do individuals limit conflict in the absence of state-made law and order? Economists have focused their energies on analyzing decision making and interaction in the context of exogenously given institutions that preclude theft, fraud, and violent appropriation. This approach assumes that state-made laws regulating conflict, and the enforcement mechanisms that support them, exist and are effective.

That assumption is problematic if one wants to understand decision making and interaction in the real world. Historically, many governments have been ineffective in providing and enforcing formal laws. For much of the course of human history, state-made law and order, at least as inhabitants of the developed world would recognize it today, did not exist (Leeson and Stringham 2005). The situation is not radically different in much of the modern world. Many modern governments are unable or unwilling to provide their citizens basic goods and services that would prevent and regulate interpersonal conflict, including law and order.

The annual Failed States Index (Foreign Policy and the Fund for Peace 2009) ranks countries based on a variety of social, economic, and political indicators. It measures "state capacity”-governments' functionality and vulnerability to collapse throughout the world. Of the 177 countries ranked in the 2009 index, 38 have an "alert" status. 93 are in "warning” mode. Only 33 countries have a "moderate" status. And only 13 are categorized as "sustainable." If we measure state failure by counting those countries that already have failing states ("alert") and those that are on the verge of failing ("warning"), nearly three quarters of the world's governments are highly dysfunctional and either on or near the cusp of implosion. Strong and effective government is the exception, not the rule. 
Even in the developed world, where government exists and is much more effective, statemade institutions for limiting conflict cannot be everywhere at all times. Further, they are costly and imperfect. In highly developed economies, too, trust plays an important role in many, if not most, interactions, suggesting that formal laws, courts, and police do not exhaustively explain why cooperation rather than conflict characterizes most relationships. ${ }^{1}$

This chapter investigates the institutions that promote cooperation and inhibit conflict where states do not: norms. Norms are privately created rules and mechanisms of enforcement that define and support property rights. ${ }^{2}$ We argue that these norms emerge and successfully limit conflict in a wider range of problem situations than often thought. ${ }^{3}$

Conventional wisdom sees some scope for norms' successful operation. However, it suggests that norms are unlikely to be able to limit conflict among individuals dedicated to creating conflict as a way of life, among socially diverse individuals, and where the prospect of violence is significant. We show that this wisdom is overly pessimistic. Norms can and have successfully limited conflict among persons who earn their living by conflict, among socially distant individuals, and in the presence of violence. ${ }^{4}$

The view that norms are unlikely to emerge to govern interactions in these more difficult problem situations overlooks the fact the gains from developing conflict-inhibiting norms, or the costs of failing to do so, are larger in such situations than they are in simpler ones. This drives individuals who find themselves in the more difficult problem situations described above to

\footnotetext{
${ }^{1}$ A growing literature highlights the importance of trust and social capital for economic development and growth. See, for instance, Knack and Keefer 1997; Woolcock 1998; Francois and Zabojnik 2005; Chan 2007.

${ }^{2}$ As Ellickson (1998) points out, research on the important role that legal norms play in economic interactions is a relatively new.

${ }^{3}$ We do not cover all types of norms. For example, the emergence of international notions of "collective security" following World War II, whereby states can be collectively punished by the international community for violations, are one example of an international conflict-inhibiting norm. While such international norms are beyond the scope of our analysis, the logic of analysis could be extended to these types of conflict-inhibiting norms.

${ }^{4}$ Fuller (1964), in his work on customary law, also argues that norms emerge to govern interactions in a variety of settings, from close-knit social groups to those involving antagonists, such as states.
} 
develop norms that enhance cooperation and reduce conflict despite the greater difficulty that doing so can present.

\section{Property Rights, Conflict, and Norms}

Demsetz (1967) famously provides a theory of how property rights emerge. ${ }^{5}$ In that theory property rights are social constructs that create common expectations about inter-personal dealings. Property rights' primary purpose is to limit conflict by internalizing externalities. Their emergence depends on transactions costs and the value of the resource to which they might apply. When a resource's value rises enough to outweigh the transaction costs of creating and enforcing property rights, people establish them.

Demsetz's theory is general in the sense that the establisher and enforcer of property rights can be anyone. Government could create and enforce property rights where they did not previously exist through its system of police, courts, and formal laws. Alternatively, private actors could do so. In the latter case, norms rather than formal laws and state enforcement institutions define and enforce the property rights that emerge.

In the same way that the costs and benefits of introducing property rights in Demsetz's theory determine whether property rights come into existence in the first place, the differing costs and benefits of using government versus norms to establish and enforce property rights where they are introduced determine which of these means of establishing and enforcing property rights is relied on. As Leeson (2007d) points out, even when in principle governmentprovided property rights can provide larger net benefits than property rights provided by norms,

\footnotetext{
${ }^{5}$ Besides the papers discussed below, 0n the endogenous emergence of property rights, see also, Anderson, Benson, and Flanagan (2006), Anderson and McChesney (2002), and Umbeck (1981).
} 
in practice this is often irrelevant. The reasons for this are the ones pointed to in the Introduction. In many instances, past and present, government with the capacity and willingness to define and protect property rights did not and does not exist. Where such government does exist, the state's legal machinery can be more expensive to use than norms. For example, gossip is cheaper than lawsuits. To the extent that negative gossip is as effective in punishing property right violators and getting them to modify their behavior as lawsuits, it makes sense to rely on gossip, a norm-based enforcement mechanism, instead of lawsuits, a state-based enforcement mechanism, to enforce property rights and limit conflict.

Anderson and Hill $(1979,2004)$ examine an important case in which individuals relied on norms because government was largely absent: the $19^{\text {th }}$-century American West. Americans in search of opportunity and adventure made it to the West before government. These were individuals seeking to cash in on gold mining in California, settlers following wagon trails, and those hoping to lay claim to hitherto unowned land.

Western pioneers confronted significant potential for conflict. Clashes over mining rights, land rights, and problems of theft threatened to plunge the West into chaos. To believe popular modern-day depictions, this is exactly what happened. But as Anderson and Hill show, these depictions are mistaken. In the absence of state-made law and enforcement, norms developed among those in and on their way to the West. Because of these norms the so-called “wild West” was in fact quite tame.

To create property rights and resolve potential conflicts over land, Western pioneers created "claims associations." These associations registered settlers' property claims and arbitrated association members' land disputes. Similarly, Western pioneers created cattlemen's associations, private organizations for protecting their cattle in the largely police-less West. 
They also created mining camps to establish property rights over mining areas and resolve territorial disputes. ${ }^{6}$ As Zerbe and Anderson (2001) point out, “cultural focal points” were central to shaping the particular rulers that miners in the American West relied on to make private law and order possible.

There are many other examples of individuals relying on norms instead of government to control conflict where government was or is totally, or effectively, absent. ${ }^{7}$ For example, Benson (1988, 1989a), Leeson and Stringham (2005), and Posner (1980) document the operation of conflict-inhibiting norms in an array of primitive societies. Landa $(1981,1994)$ considers the emergence of norms to govern commercial transactions in contemporary Southeast Asia. Similarly, Greif $(1989,1993)$ analyzes the importance of norms for $11^{\text {th }}$-century Mediterranean traders.

Individuals not also use norms to control conflict where government does not exist. They also use norms to govern their relations where government does exist but norms are cheaper to use for this purpose than state-made institutions. Bernstein (1992) examines extralegal mechanisms of contract enforcement in such a context: the contemporary diamond industry. She highlights how long-standing norms within the community of diamond traders govern dispute resolution using commonly accepted rules and practices and private arbitration. Likewise, Ellickson (1991) considers the emergence of conflict-inhibiting norms in modern-day Shasta County, California. Ellickson describes how the members of this predominantly farming and ranching community create rules, resolve disputes, and enforce rules without relying on the state.

Ostrom (1990) and Ostrom, Gardner, and Walker (1994) consider individuals’ reliance on norms to create property rights and limit conflict in contexts where government normally

\footnotetext{
${ }^{6}$ Umbeck (1977) was the first to discuss legal norms in the context of the California gold rush.

${ }^{7}$ Besides those papers discussed below, see also, Dixit (2004).
} 
exists but cannot be relied on for this purpose. They focus on norms used to inhibit conflict in the context of common-pool resources, such as irrigation systems, fisheries, forests, and grazing areas in developing countries. Common-pool resources are rivalrous but non-excludable. This makes them subject to the tragedy of the commons. Government can resolve tragedy of the commons-created conflict by taking ownership of such resources and establishing regulations for their use. Alternatively, common pool resources can be privatized. This also overcomes tragedy of the commons-created resource conflict.

However, in many cases, neither government ownership and regulation nor traditional private ownership of common-pool resources is a practical solution to such conflict. In developing countries, constrained state capacity limits individuals' ability to rely on the former method of controlling conflict. Further, deeply rooted cultural ideas about fairness often prevent the latter method from being practicable. Norms, which neither rely on state-created rules or enforcement mechanisms, nor necessarily put resources in the hands of individual private users, provide a third way to limit conflict over resources in the face of common-pool problems.

Norms of enforcement ensure compliance with property norms and rules governing individuals' behavior. To do this, norms of enforcement often leverage individuals' concern for their reputations. For example, as Anderson and Hill $(1979,2004)$ discuss, in the American West, land club rules were enforced through boycott and ostracism. If a club member refused to abide by the ruling of the arbitrators who adjudicated his dispute, he lost his standing with other club members. The association's members expelled non-compliant members from the association and refused to interact with them, commercially or personally.

Similarly, Greif’s $(1989,1993)$ Maghribi trader coalition relied on reputation to enforce agreements and ensure compliance with its established standards of conduct. If a trader cheated, 
his reputation was damaged and other traders would avoid interacting with him in the future. Traders' reputations acted as bonds that held them accountable for their actions. As Bernstein (1992) points out, participants in the diamond industry enforce their norms through reputation as well. Norm-violating industry members may be expelled from the community and boycotted. Similarly, Ellickson (1991) describes how citizens of Shasta County use the threat of negative gossip, and in more extreme cases private reprisals, such as injuring another's straying cattle, to enforce the norms governing their relations.

The substantive specifics of norms and their enforcement mechanisms depend on the specifics of the potential conflict situation they emerge to resolve. For example, Ellickson (1989) describes how different norms emerged among whalers who hunted different species of whale in the $18^{\text {th }}$ and $19^{\text {th }}$ centuries. These norms were tailored to the particulars of the potential conflict situation that different whalers faced. All whalers confronted the problem of establishing who had rightful claim to prey: The first whaler to harpoon a whale? The whaler that ultimately killed the whale? The whaler that did the most to incapacitate the whale? However, because the kinds of whales they hunted behaved differently, different property norms effectively prevented conflict in different whalers' particular cases, leading different property norms to develop in these cases.

Off Greenland, British whalers established the norm of "fast fish, loose fish.” According to this norm, the first whaler to harpoon a whale was its rightful owner as long as the line going from the harpooned whale to the whaler was never broken. If it was, the whale became fair game for other whalers. This norm created a bright-line rule about who was the rightful owner of the whale. It was efficient for whalers in this context because the species of whale hunted off Greenland moved slowly and was unlikely to break the line. The fast fish, loose fish norm 
therefore tended to reward the first harpooner, which was the most difficult part of the hunt. It incentivized whalers to undertake the arduous task of harpooning the whale. It discouraged whalers from attempting to free ride on the efforts of others by attacking a whale already weakened by the efforts of the first harpooner.

In contrast, American whalers, who hunted sperm whales, developed a different norm to establish property rights over whales. That norm was called "iron holds the whale.” It stipulated that the first harpooner had the right to the whale, whether the line broke or not, if he remained in its pursuit. Iron holds the whale was an efficient norm for whalers of sperm whales since it incentivized them to undertake the most difficult part of hunting as above-first strike. It prevented free riders despite the fact that sperm whales were fast movers and likely to break the line.

The existing literature that examines norms documents the emergence and operation of norms in a variety of contexts. However, these contexts tend to display common characteristics that, for reasons we discuss below, make it relatively easy for norms to emerge and function. The communities in which norms emerge that the existing literature focuses on tend to be small and close knit. Norms normally emerge to prevent "peaceful conflict," such as contract repudiation, rather than to prevent "violent conflict," such as that which exists when individuals are bitter, avowed enemies of one another. Further, the individuals whose interactions give rise to norms, and to whose interactions these norms are supposed to apply, tend to be law-abiding persons who are willing to behave opportunistically in some cases, but whose internal restraints prevent them from taking advantage of every opportunity to prey on others. Such persons are different from professional criminals who are more likely to lack internal restraints and who earn their living by violating others’ property rights. 
In the sections that follow we consider the emergence of conflict-inhibiting norms in contexts that present more difficult problem situations because they lack one or more of the features noted above. First, we consider norms in outlaw communities-among individuals who have made violating property a way of life. Next we consider the emergence of norms among socially diverse individuals. Finally, we investigate the possibility of conflict-inhibiting norms where violence is not only likely, but virtually assured by virtue of long-standing war-like relations between hostiles.

\section{Outlaws}

Professional criminals are dedicated to violating others' property rights. This is their way of living. It seems unlikely, then, that they would be able to develop norms devoted to inhibiting conflict. But there is a problem with this intuition: professional criminals, perhaps more than anyone, require privately created rules of social order to function.

There are two reasons for this. First, unlike legitimate citizens, criminals cannot typically rely on state-made laws or enforcement mechanisms to secure cooperation. ${ }^{8}$ This is problematic since, to realize many of their goals, criminals must work in cooperation with one another to maximize profits. A pickpocket can "produce” by himself. But larger-scale criminal enterprises require team production. If such criminals cannot develop conflict-inhibiting norms, they have no hopes of facilitating such production.

Second, unlike legitimate producers, professional criminals have demonstrated an unbridled willingness to plunder others. They may have less compunction about creating conflict—a weaker internal moral compass that might restrain their predation-than legitimate

\footnotetext{
${ }^{8}$ If public officials are corrupt, criminals can use state-made institutions to further their ends and promote
} cooperation between them, for example by helping them exclude potential competitors. 
persons tend to have. Thus if norms do not emerge to govern their interactions, criminals have little hope of limiting conflict. Together with the fact that professional criminals cannot rely on state-made system of law and order, this suggests that the need for "honor among thieves" is stronger than the need for honor among legitimate persons. The greater urgency outlaws confront in this regards explains why, perhaps surprisingly, norms inside their communities are common and effective (Leeson and Skarbek 2010).

One of the clearest examples of this is the order achieved by communities of $18^{\text {th }}$-century Caribbean pirates. The Caribbean pirates are history's most notorious criminals. They included men such as Edward Teach, the infamous pirate better known as Blackbeard, "Calico Jack" Rackam, "Black Bart" Roberts, and others. The Caribbean pirates plied the seas of the Caribbean, North America's Atlantic sea coast, the Gulf of Mexico, and parts of the Indian Ocean. They made their living by plundering merchant ships that transacted Europe's growing trade in the first decades of the $18^{\text {th }}$ century.

As Leeson (2007a, 2009a, 2009b) describes, most of the Caribbean pirates operated out of a land base in the Bahamas. But their more enduring communities were their floating ones: pirate crews. Piracy required joint production. A one-man pirate crew was not possible. Multiple pirates were needed to man and operate pirate ships. The average pirate crew had 80 members. But larger crews, some of several hundred, were not uncommon. To prevent intercrewmember conflict from leading their crews to implode, pirates required conflict-inhibiting norms that could secure their cooperation.

The potential conflict situations that pirates confronted are predictable. Theft and fighting posed the most immediate threats. If pirates could not restrain their criminal inclinations among each other, they could not cooperate for mutual gain. In addition to this, various negative 
externalities also created dangerous specters for pirate crews. Activities such as drinking and gambling threatened to create conflicts between crewmembers. These conflicts were not only capable of undermining crew morale. They could quite literally tear the crew apart. Intercrewmember violence with cutlasses and blunderbusses could damage the ship irreparably or start onboard fires that ignited gunpowder, blowing the crew to pieces.

To prevent such conflict, pirates developed a set of norms known today as "pirate codes.” We know about the content of these codes because, remarkably, pirates wrote them down. Pirates called these systems of norms "articles of agreement." Pirate articles resembled constitutions. Consider the set of articles that governed pirate captain Bartholomew Roberts' crew (Johnson 1726-1728 [1999]): ${ }^{9}$

I. Every Man has a Vote in the Affairs of Moment; has equal Title to the fresh Provisions, or strong Liquors, at any Time seized, and may use them at Pleasure, unless a Scarcity make it necessary, for the Good of all, to vote a Retrenchment.

II. Every Man to be called fairly in Turn, by List, on board of Prizes, because, (over and above their proper Share) they were on these Occasions allowed a Shift of Cloaths: But if they defrauded the Company to the Value of a Dollar, in Plate, Jewels, or Money, Marooning was their Punishment. If the Robbery was only betwixt one another, they contented themselves with slitting the Ears and Nose of him that was Guilty, and set him on Shore, not in an uninhabited Place, but somewhere, where he was sure to encounter Hardships.

III. No person to Game at Cards or Dice for Money.

IV. The Lights and Candles to be put out at eight a-Clock at Night: If any of the Crew, after that Hour, still remained enclined for Drinking, they were to do it on the open Deck.

\footnotetext{
${ }^{9}$ Italics from the original have been removed.
} 
V. To keep their Piece, Pistols, and Cutlash clean, and fit for Service.

VI. No Boy or Woman to be allowed amongst them. If any Man were found seducing any of the latter Sex, and carry'd her to Sea, disguised, he was to suffer Death.

VII. To Desert the Ship, or their Quarters in Battle, was punished with Death or Marooning.

VIII. No striking one another on board, but every Man's Quarrels to be ended on Shore, at Sword and Pistol.

IX. No Man to talk of breaking up their Way of Living, till each shared a $1000 \mathrm{l}$. If in order to this, any Man should lose a Limb, or become a Cripple in their Service, he was to have 800 Dollars, out of the public Stock, and for lesser Hurts, proportionately.

X. The Captain and Quarter-Master to receive two Shares of a Prize; the Master, Boatswain, and Gunner, one Share and a half, and other Officers one and a Quarter.

XI. The Musicians to have Rest on the Sabbath Day, but the other six Days and Nights, none without special Favour.

The norms embodied in such "pirate codes" performed all the major functions that sea dogs required. They prohibited theft and fighting. They also regulated negative externality generating behaviors, such as drinking and gambling, which threatened to create inter-pirate conflicts that could damage the ship or injure other members of the crew. Other pirate crews' norms, such as those that governed Captain John Phillips' pirate crew, regulated smoking since careless smoking could blow up the ship.

Pirates’ norms created enforcement mechanisms for their rules. Pirates created a special officer, the quartermaster, to administer these punishments. Punishments tended to be physical in nature, such as lashings, marooning and, in extreme cases, death. To resolve inter- 
crewmember disputes, pirates' system of norms also relied on quartermasters, who adjudicated conflicts. When the quartermaster's adjudication failed, he refereed duels between the disputants on land to prevent violence from spilling over on to the other members of the crew. Pirate norms also created an early form of workers' compensation: crewmembers injured on the job received insurance payments from the crew's common stock. This norm helped prevent piratical free riding and encouraged pirates to give their full effort during battle by reducing the cost of putting oneself in the way of danger when pirating.

Conflict between ordinary crewmembers was not the only kind of conflict that pirates confronted. They confronted another important source of potential conflict: conflict between the leadership, the pirate captain, and the rest of the crew. Like legitimate enterprises' leaders, pirate crews' leaders exercised powers that, when wielded appropriately, were critical to crews' success. However, pirate leaders could also abuse these powers, which would undermine interpirate cooperation.

Pirates needed officers to lead them in battle with prey, distribute booty and provisions, and enforce their norms. The problem was that self-interested leaders could use their authority over these activities to benefit themselves at other crewmembers' expense. For example, leaders could order their personal enemies to dangerous posts during battle, skim booty and provisions, and use their enforcement powers to settle personal scores.

To address these problems, pirate norms established a system of democratically divided power. Per their articles, pirates democratically elected their captains and quartermasters. This permitted them to popularly depose unscrupulous officers and elect new ones in their place. If captains and quartermasters wanted to retain their positions, they needed to use the powers their crews endowed them with for their crews' benefit rather than their own. 
Pirates also divided important powers between their officers. Captains were given autocratic decision-making power in times of battle. But at all other times they wielded no more power than ordinary members of the crew. Other important authorities, such as booty and provision distribution and rule enforcement, were delegated to the quartermaster. By dividing authority in this way, pirate norms limited their leaders' ability to prey on them for private benefit.

As a result of their system of norms, pirates successfully limited conflict, permitting them to work together and, in some cases, steal incredible sums. Pirate norms were imperfect, of course. But according to one historian, because of their norms, pirate ships were more orderly, peaceful, and well organized than many merchant ships, vessels of the Royal Navy, or even the British colonies (Rogozinski 2000: 179). As one $18^{\text {th }}$-century observer described it, “At sea, they perform their duties with a great deal of order, better even than on the Ships of the Dutch East India Company; the pirates take a great deal of pride in doing things right” (Rogozinski 2000: viii).

Caribbean pirates' communities are not the only communities of professional criminals where norms operate successfully. Gambetta (1993) and Leeson and Rogers (2010) have examined the norms that govern members of the Sicilian Mafia. Skarbek (2010) explores norms in the context of prison gangs. And Leeson and Skarbek (2010) point to the near-ubiquity of norms across criminal communities. Precisely because they are criminal, none of these groups can use state-made institutions to prevent internal conflict. Instead they rely on norms instead to promote inter-criminal cooperation. 


\section{Social Diversity}

Most cases of conflict-inhibiting norms discussed in the literature describe the emergence and operation of norms in small, socially homogenous populations. Ellickson's whalers and Shasta County ranchers and farmers, Bernstein’s diamond dealers, Ostrom’s common-pool resource users, Anderson and Hill's western pioneers, Greif's Maghribi traders, and even the Caribbean pirate crews discussed above formed tight-knit, socially close groups.

There is a reason for this focus. Norm-based rules emerge more easily where the individuals they apply to share common ideas about what constitutes legitimate versus illegitimate behaviors and how the latter should be responded to. Landa (1981, 1994), for instance, emphasizes the importance of social homogeneity to the operation of norms within “ethnically homogeneous middlemen groups” in Southeast Asia. Similarly, Leeson (2010) demonstrates how the emergence of conflict-inhibiting norms on $18^{\text {th }}$-century merchant ships, which facilitated disgruntled sailors' ability to coordinate mutinies, relied on the close-knit relationships between merchant seamen. When individuals are socially close, certain rules of interaction are focal. ${ }^{10}$ To the extent that these rules promote cooperation instead of conflict, it is not difficult for conflict-inhibiting norms to emerge and operate effectively.

Social closeness is particularly important to norms' enforcement. As the discussion in section 2 highlighted, norms are commonly enforced through reputation-based mechanisms. The idea behind these enforcement norms is straightforward: cooperation can be enforced where rule violation is punished by the prospect of foregone income resulting from community ostracism in future dealings. If individuals are sufficiently patient, a loss of reputation generated by a rule violation today creates even larger losses in terms of foregone revenues from potential future

\footnotetext{
${ }^{10}$ On the importance of focal points for coordinating cooperative behavior and limiting conflict, see Leeson, Coyne, and Boettke (2006).
} 
interactions, facilitating rule compliance. Norm-enforcement mechanisms based on such logic rely on continuous dealings and the shadow of the future to ensure cooperation.

As Skaperdas (2003) points out, “folk theorem”-type mechanisms, such as that which reputation depends on, have been overrated as a solution to the problem of conflict. They describe only the possibility of cooperation. Conflict-ridden equilbria also remain possible. Further, as Skaperdas and Syropoulos (1996), Garfinkel and Skaperdas (2000), and Skaperdas (2003) show, under certain circumstances the shadow of the future can increase the prospect of conflict rather than reduce it.

There is another potential problem with such mechanisms as a means of enforcing norms: they require individuals to be able to communicate violators' identity to a sufficient number of others. The strength of individuals' ability to punish cheaters through boycott, and thus the strength of their incentive to comply with norms, depends on the proportion of people that a potential cheater might interact with that punishes him if he cheats. Bilateral punishment, whereby an individual refuses to interact again with someone who has cheated him, may not be sufficient to prevent a cheater from cheating. If he is impatient, a cheater may find it worthwhile to defraud his exchange partner despite the fact that he loses future exchange possibilities with the person he defrauds. However, if by cheating his exchange partner the cheater loses future exchange opportunities with everyone else he might trade with, the punishment he suffers for cheating is much larger-large enough to prevent him from cheating despite his high discount rate. Multilateral punishment is therefore a much more effective norm-enforcement mechanism.

When prospective traders are socially distant—when they are the members of different social groups—widespread multilateral punishment is much more difficult to achieve. It may be easy to coordinate the members of one's own social group on ostracizing an outsider who cheats. 
But it is much harder to coordinate the members of the outsider's social group on this punishment. Members of the outsider's social group may not trust the claims made by the members of the other group. If different languages are involved, it may be difficult to communicate the fact that cheating has occurred to the members of the outsider's social group. Further, the members of the outsider's social group may have different ideas about what constitutes cheating and how cheating should be punished. They may not consider the alleged act of cheating to be fraudulent at all. Even if they do, they may not see ostracism as the appropriate punishment.

This limit on reputation-based enforcement has contributed to a belief that norms are likely to be ineffective, or even impossible, when they apply to socially diverse individuals. If that belief is correct, norms' effectiveness is limited indeed. Most of the gains of cooperation lie outside individuals' small, tight-knit groups. If norms cannot inhibit conflict when the members of separate social groups are involved, they cannot help individuals realize the widespread benefits from exchange. Their cooperation-enhancing abilities are severely circumscribed.

The limits to reputation-based enforcement mechanisms for enforcing norms that could govern inter-group interactions are highly sensible. Yet, historically, we observe cooperation between the members of different social groups without significant reliance on state-based institutions for preventing conflict (Leeson 2006, 2008). Norms rooted in something other than reputation-based enforcement alone must have facilitated this cooperation.

We can get a sense of what additional norms have supported inter-group cooperation by examining international trade in the Middle Ages. In the absence of state-made institutions to control conflict, socially diverse international traders relied on a customary, norm-based legal system to facilitate trade. Benson (1989b) and Milgrom, North, and Weingast (1990) document 
the spontaneous evolution of international commercial law in the Middle Ages. Medieval merchants throughout Europe were separated by language, distance, and local law. To facilitate trade a common set of commercial rules was needed. Out of this need emerged what has subsequently been termed the lex mercatoria, or Law Merchant. The Law Merchant was a system of norms for governing international commercial transactions. It developed out of merchants' commercial customs and shared legal notions. Roman law (the ius gentium) provided many of these notions, which merchants modified to meet their special needs. These rules were privately established, adjudicated, and enforced.

Under the Law Merchant commercial disputes were arbitrated in “dusty feet courts,” socalled because of the traders' dusty feet as they traveled between commercial fairs. Merchants themselves presided over these courts. Their decisions were not formally binding. Reputation and boycott played an important role in the enforcement of these courts' decisions. However, for the reasons discussed above, they alone could not be relied on to prevent conflict between international traders.

Leeson $(2006,2008)$ discusses the norms that supported cooperation between socially distant traders. ${ }^{11}$ Traders screened outsiders by looking for signals that informed them about whether the outsiders they were considering trading with were likely to behave honestly or not. Unlike reputation-based multilateral punishments, such as ostracism or boycott, screening does not depend on social closeness to work. Successful screening does, however, require two things: easily observable attributes or activities—signals — that individuals may adopt or undertake to indicate their credibility to outsiders, and signals with an appropriate cost structure-namely signals that are cheap for cooperative types to send but expensive for cheaters to send-to

\footnotetext{
${ }^{11}$ Leeson (2005) considers the operation of the mechanism described below in facilitating inter-group trade in precolonial Africa.
} 
effectively convey their credibility to outside potential trading partners they wish to exchange with.

Signals that shrink the social distance between two individuals satisfy both of these conditions. If two individuals, $A$ and $B$, are socially distant, and $A$ desires to trade with $B, A$ can adopt certain customs or practices that belong to $B$ and in doing so signal his trustworthiness in trade. A can use "social distance-reducing signals" to enable exchange with $B$. For instance, $A$ might learn B's language, convert to his religion, engage in his customs for settling disputes, or adopt some other practice of B's that reduces the social distance between them. These attributes are all easily observable. More important, it costs more for individuals with high discount rates-individuals who are more likely to cheat-to invest in such signals than it costs individuals with low discount rates_-individuals who are less likely to cheat.

An individual's payoff from reducing the social distance between himself and an outsider is long term. If the social distance-reducing investment is sufficiently costly, the cost of investing in such a signal can only be recouped through repeated interactions with the members of that outsiders' social group over time. $B$ cannot easily coordinate a boycott of $A$ by the member's of $A$ 's social group. But he can coordinate a boycott of $A$ by the members of his own social group. Since $A$, if he is a cheater, discounts the gains from future exchange with the members of $B$ 's social group more heavily than he does if he is not a cheater, $A$ finds it more costly to invest in reducing social distance with $B$ if he is likely to cheat $B$ than if he is not likely to do so. Investments in social distance-reducing signals are correlated with the sender's honesty. Thus if $B$ observes that $A$ has invested sufficiently in reducing their social distance, he can be confident that $A$ is unlikely to cheat. So he trades with him. If $B$ does not observe this investment, he knows that $A$ is likely to be a cheater. So he refrains from trading with him. 
Medieval international traders leveraged this mechanism to facilitate exchange under the Law Merchant by adopting the religion, manners, style of dress, language, and customs of outsiders they desired to trade with. Perhaps most significantly, traders' voluntary submission to the business and arbitration practices embodied in the norms of the Law Merchant itself constituted investments in important social distance-reducing signals. By relying on such signals, individuals were able to promote cooperation and prevent conflict in transactions governed by norms despite their social diversity.

\section{Violence}

To prevent "peaceful" forms of conflict, such as theft, fraud, and contractual default, norms based on reputation or costly signals can be effective. But boycott and screening are often ineffective in the face of violence. They do not discourage physically stronger individuals from using their strength superiority to overwhelm weaker ones. A weaker individual may announce his intention never to deal again with anyone who cheats him. He may also limit his interactions to individuals who have invested in social distance-reducing signals. But this does not prevent physically stronger individuals from using force to take what they want from weaker ones.

For this reason it is common to conclude that conflict-inhibiting norms are unlikely to emerge or to be effective when the conflict they are supposed to inhibit involves physical violence. ${ }^{12}$ This is especially so when the prospect of violence is not only possible because of asymmetric strengths, but is virtually guaranteed because individuals are long-standing enemies of one another. If violence cannot be regulated, individuals face the most serious sort of problem. Society degenerates into the Hobbesian war of all against all.

\footnotetext{
${ }^{12}$ For theoretical discussions of cooperation and violent conflict under anarchy, see, for instance, Bush and Mayer (1974), Hirshleifer (1995, 2001), and Skaperdas (1992, 2003).
} 
Skaperdas (1992) demonstrates the possibility of cooperation, even in one-shot interactions, when individuals may behave violently toward one another. A handful of papers have considered conflict-inhibiting norms in the context of violence historically. Friedman's (1979) analysis of medieval Iceland's legal system is one of the earliest examples of this. Anderson and Hill's $(1979,2004)$ treatment of private protection agencies in the $19^{\text {th }}$-century American West is another. More recently, Leeson (2007b) examines the norms that interior producers and middlemen developed in precolonial western Africa to transform the latter's incentive from violent banditry to peaceful exchange. ${ }^{13}$

Perhaps surprisingly, norms have emerged to limit conflict not only amidst the threat of pervasive violence, but when the perpetrators of violent conflict are bitter enemies of one another. ${ }^{14}$ Leeson (2009c) analyzes the endogenous legal system that emerged to govern relations between such hostiles on opposite sides of the Anglo-Scottish border between the $13^{\text {th }}$ and $16^{\text {th }}$ centuries. This episode illustrates the emergence and operation of norms amidst violence. It also exposes the means by which such norms could be enforced given the inability of reputation or signaling to do so alone.

Until the $17^{\text {th }}$ century, the borderlands between England and Scotland consisted of six territories—-three on each side—called the English and Scottish "marches." The borderlands constituted a formally ungoverned interstice for interactions involving inhabitants from both realms. Neither England's nor Scotland's domestic laws extended across the border to the other side's inhabitants. In this sense the borderlands were anarchic. There was no formal

\footnotetext{
${ }^{13}$ See, also, Anderson and McChesney (1994) for an excellent discussion of the "raid or trade" decision of Indians and whites.

${ }^{14}$ Axelrod (1984) and Leeson and Nowrasteh (2010) also consider the emergence of norms to regulate violence between hostiles. Axelrod considers such norms in the context of British and German soldiers engaged in trench warfare during WWI. Leeson and Nowrasteh consider legal norms that emerged to limit the social cost of maritime warfare in the context of privateer-merchantman interactions in the age of sail. Pospisil (1958) considers norms governing war between primitive tribes.
} 
supranational authority to create or enforce laws that dealt with cross-border crime-criminal acts perpetrated by citizens on one side of the border against those on the other.

This was particularly problematic because the medieval Anglo-Scottish border was home to the infamous "border reiver," that sizeable class of cross-border marauder memorialized in the poetry of Sir Walter Scott. "Reiving” involved violently raiding inhabitants on the opposite side of the border. It included maiming, murder, arson and whatever other coercive means were necessary to plunder what was desired. The border reivers were deeply committed to this system of plunder. Violent theft was not an occasional activity for them. It was their way of life.

For much of the 250-year period between the first War of Scottish Independence in 1296 and the Treaty of Norham in 1551, England and Scotland were in open conflict with one another. Since the borderlands separated the warring nations, many of the border people were embroiled in this conflict, facing one another in battles during official Anglo-Scottish war and often existing in a state of undeclared conflict with one another when official war was not raging. March inhabitants grew to be bitter enemies of their counterparts on the opposite side of the frontier. The absence of a supranational sovereign to regulate the cross-border reiving system threatened to plunge the borders into bloody mayhem.

In the same way that the lex mercatoria emerged in the $11^{\text {th }}$ as a system of norms to inhibit “peaceful conflict” between international traders, such as fraud and contractual default, a system of norms emerged in the medieval Anglo-Scottish borderlands to inhibit violent conflict between reivers. That system of norms, grounded in ancient cross-border custom, is called the "leges marchiarum," or laws of the marches. The norms enshrined in the leges marchiarum dealt primarily with cross-border violence, including murder, violent theft, maiming, and so on. 
Rather than seeking to eliminate violence completely, which was impossible amidst the border people who were not interested in eradicating the reiving system, the leges marchiarum had the more modest goal of regulating and taming reiving activity. It achieved this by outlawing certain activities, such as murder, but also by permitting various other violent activities subject to certain rules.

For example, according to the norms embodied in the laws of the marches, borderers were permitted to engage in "trod" whereby inhabitants who were the victims of cross-border theft could lawfully pursue their enemy into the opposite realm and slaughter him if he were caught "reed hand." Violent self-help was regulated, however. Under the norms of the borderlands, the pursuer had to announce his intention to the others he encountered in the foreign realm into which he traveled. Further, there was a statute of limitation on when he could pursue this form of reprisal, which the borderers called "hot trod." If a certain amount of time expired between the time of the alleged theft and the pursuit, the pursuer was required to follow what was called "cold trod” instead. Cold trod was governed by a different set of more restrictive rules. The purpose of trod rules was to prevent the legitimate pursuit of thieves from devolving into virtual Anglo-Scottish wars, limiting the extent of violent conflict.

To enforce the norms of the leges marchiarum the borders developed an institution known as the "day of truce.” The day of truce was a court-like institution that met monthly to settle cross-border disputes and address violations of border norms. At the day of truce each side created “juries" - the English side selecting six Scotsmen for the task and the Scottish side selecting six Englishmen. The English jury heard the Scottish complaints and vice versa. These juries decided whether a border rule had been violated and what border custom dictated was the appropriate punishment. 
The day of truce accomplished for typically violent rule violations in its context what the Law Merchant’s “dusty feet courts" accomplished for "peaceful” (i.e., commercial) rule violations in its context. Since day of truce institution did not fall under the purview of a supranational sovereign, its decisions could not be formally enforced. Enforcement norms were therefore important to ensuring compliance with day of truce decisions.

Borderland enforcement norms leveraged both reputation-like mechanisms and the threat of violence to accomplish this compliance. For example, one enforcement norm, which worked essentially like reputation, was bonding. Bonding involved the use of human hostagestypically a family member of the accused/guilty or failing this one of his fellow clansmen. Under this institution a “fouled” borderer (borderers' term for convicted norm violators) posted a literal hostage instead of his reputation as a guarantee that he would comply with day of truce decisions. For example, if a borderer was convicted by the jury at the day of truce and refused to comply with the jury's decision, a family member or fellow clansmen would be sent with the aggrieved as an assurance until he complied.

But since reputation alone could not solve all enforcement problems in the face of violence, border custom also relied on the threat of violence to enforce norms. The deadly feud is one example of this. As its name suggests, the deadly feud was a violent institution involving the protracted slaughter of another's family. Murdering a man, for example, in violation of border norms, could result in violent retribution by the murdered man's clan. Usually, in response to this, the clan of the original aggressor would respond in kind. A deadly back and forth would ensue between the two clans. If launched, a deadly feud could result in many deaths on both sides. Given a mutual, credible expectation of this response to unlawfully aggressing against the member of another clan, the cost of doing so was extremely high. This expectation 
created by the deadly feud provided a powerful incentive to behave within the bounds of border norms in the first place. In this way the threat of awful violence was used to enforce norms against violence itself where reputation alone, for example, could not.

The border people's conflict-inhibiting norms are an example of a far wider practice that many clan-organized societies, from Sicily, Albania, and Crete, to the Arabian Peninsula and the Pashtuns of Afghanistan, employed in various forms. As the preceding discussion indicates, these norms were highly imperfect. They did not eliminate violence or even come close to doing so. Out of equilibrium they could be destructive and prolonged, causing economic and social disruptions. This suggests that they are not welladapted to a modern economy and polity. However, considering the deeply rooted social system based on plunder that the border people were part of, the norms that the leges marchiarum embodied were quite successful. They prevented individuals whose way of life was predicated on violent conflict from annihilating one another. They inhibited cross-border violent acts from degenerating into the Hobbesian jungle. The border people's norms did not eradicate violence. But they bounded and regulated it, preventing deadly chaos in a society dedicated to plunder.

\section{Directions for Future Research}

We have pointed to only a few examples of conflict-inhibiting norms in contexts that present difficult problem situations - when conventional wisdom suggests such norms are unlikely to emerge or function. Rather than compiling additional cases of norms in the easier problem situations that much of the existing literature examines, future research should delve deeper into the questions that norms pose in the context of these more difficult scenarios. We have tried to 
demonstrate that there is in fact something to explore here. But much work remains to be done in moving beyond documenting the mere existence and operation of norms in such contexts.

Given the special importance of norms for the bulk of the developing world where state institutions are absent or dysfunctional, future research should examine the relative welfare properties of societies based entirely, or predominantly, on private norms versus societies based on corrupt and dysfunctional governments. In many developing countries, government hangs on only by a thread provided by the international development community. Depending on norms' effectiveness, it is possible that citizens in these countries could be better off if their corrupt and failed states were allowed to collapse, and anarchy, which as we discussed above is governed by norms, were allowed to take its place. Conflict-inhibiting norms can and do fail. But so do governments, especially in the developing world. The question, then, is which fails worse (Leeson and Williamson 2009).

Leeson’s (2007c) examination of Somalia, which has no government at all, suggests that the answer to this question is not as obvious as one might initially expect. He considers all available development indicators that allow a before-and-after comparison of Somali's welfare around the time that Somalia's dysfunctional government collapsed and anarchy emerged in 1991. Leeson finds that on nearly every available indicator, Somali welfare has improved under anarchy, partly because of the norms developed to govern Somalia under statelessness. Notably, the data he considers suggest that Somalia's northern territories, Puntland and Somaliland, where "microstates" exist (if one is willing to consider an entity that lacks the power to tax a state), are not the only locations of this improvement. Indeed, southern Somalia actually outperforms Puntland or Somaliland on several indicators. 
Coyne (2006) considers the conflict-inhibiting norms that emerged in Somalia under statelessness that contributed to these improvements. ${ }^{15}$ For example, within Somali clans, "diyapaying groups” ranging from several hundred to several thousand members operate on the basis of a system of norms that governs intra-clan interactions. Each diya-paying group is an alliance of related lineages formed via contract. That contract states that members of the alliance should pay and receive blood compensation—“diya”-together, creating a system of social insurance and collective responsibility. If a group member is injured, the diya contract stipulates who is to pay to assist the injured member. If a group member it is attacked, it stipulates how other group members are to respond to the attacker, and so on.

To regulate interactions between the members of different clans, Somalis rely on a customary system of norms called heer. Heer regulates inter-clan common pool resource use and other sources of potential conflict. An inter-clan council of lineage leaders-the Guurtienforces sanctions against violations of heer. Somali norms are imperfect. Still, both intra-clan (diya-paying groups) and inter-clan (heer) norms have helped citizens overcome conflict in the absence of government and promoted Somali progress under anarchy.

Whether there is something exceptional about Somalia's norms among least-developed countries or its political economy more generally that accounts for its improvement under a system that defines and enforces property rights and regulates conflict entirely on the basis of norms is an empirical question that deserves further investigation. In either case Somalia highlights an important fact for social scientists interested in understanding the causes and consequences of the wealth and poverty of nations: they cannot be understood apart from norms.

\footnotetext{
${ }^{15}$ For a discussion of norm development as a kind of entrepreneurial act in developing countries, and in the Somali context in particular, see Leeson and Boettke (2009).
} 


\section{References}

Anderson, Terry L., Bruce L. Benson, and Thomas E. Flanagan. 2006. Self-Determination: The Other Path for Native Americans. Stanford: Stanford University Press.

Anderson, Terry L. and Peter J. Hill. 1979. “An American Experiment in Anarcho-Capitalism: The Not so Wild, Wild West,” Journal of Libertarian Studies 3: 9-29.

. 2004. The Not so Wild, Wild West: Property Rights on the Frontier. Stanford, CA: Stanford University Press.

Anderson, Terry L. and Fred S. McChesney. 1994. "Raid or Trade? An Economic Model of Indian-White Relations,” Journal of Law and Economics 37: 39-74. ed. 2002. Property Rights: Cooperation, Conflict, and Law. Princeton, N.J.: Princeton University Press.

Axelrod, Robert. 1984. The Evolution of Cooperation. New York: Basic Books.

Benson, Bruce L. 1988. “Legal Evolution in Primitive Societies,” Journal of Institutional and Theoretical Economics 144: 772-788.

. 1989a. "Enforcement of Private Property Rights in Primitive Societies: Law without Government,” Journal of Libertarian Studies 9: 1-26.

. 1989b. “The Spontaneous Evolution of Commercial Law,” Southern Economic Journal 55: 644-661.

Bernstein, Lisa. 1992. “Opting Out of the Legal System: Extralegal Contractual Relations in the Diamond Industry,” Journal of Legal Studies 21: 115-157.

Bush, Winston C., and Lawrence S. Mayer. 1974. "Some Implications of Anarchy for the Distribution of Property Rights,” Journal of Economic Theory 8: 401-12.

Chan, Kenneth S. 2007. “Trade, Social Values, and the Generalized Trust,” Southern Economic Journal 73: 733-753.

Coyne, Christopher J. 2006. "Reconstructing Weak and Failed States: Foreign Intervention and the Nirvana Fallacy,” Foreign Policy Analysis 2: 343-360.

Demsetz, Harold. 1967. “Toward a Theory of Property Rights,” American Economic Review 57: 347-359.

Dixit, Avinash K. 2004. Lawlessness and Economics: Alternative Modes of Governance. Princeton: Princeton University Press. 
Ellickson, Robert C. 1989. "A Hypothesis of Wealth-Maximizing Norms: Evidence from the Whaling Industry,” Journal of Law, Economics, and Organization 5: 83-97.

. 1991. Order without Law: How Neighbors Settle Disputes. Cambridge, MA: Harvard University Press.

1998. "Law and Economics Discovers Social Norms,” Journal of Legal Studies 27: 537552.

Foreign Policy and the Fund for Peace. 2009. "Failed States Index.” Available at: http://www.fundforpeace.org/web/index.php?option=com_content\&task=view\&id=99\&It emid $=323$

Francois, Patrick and Jan Zabojnik. 2005. "Trust, Social Capital and Economic Development,” Journal of European Economic Association 3: 51-94.

Friedman, David. 1979. "Private Creation and Enforcement of Law—A Historical Case,” Journal of Legal Studies 8: 399-415.

Fuller, Lon L. 1964. The Morality of Law. New Haven: Yale University Press.

Gambetta, Diego. 1993. The Sicilian Mafia: The Business of Private Protection. Cambridge, MA: Harvard University Press.

Garfinkel, Michelle R. and Stergios Skaperdas. 1996. "Conflict without Misperception or Incomplete Information: How the Future Matters," Journal of Conflict Resolution 44: 793-807.

Greif, Avner. 1989. "Reputation and Coalitions in Medieval Trade: Evidence on the Maghribi Traders,” Journal of Economic History 49: 857-882.

—. 1993. "Contract Enforceability and Economic Institutions in Early Trade: The Maghribi Traders' Coalition,” American Economic Review 83: 525-548.

Hirshleifer, Jack. 1995. “Anarchy and Its Breakdown,” Journal of Political Economy 103: 2652. . 2001. The Dark Side of the Force. New York: Cambridge University Press.

Johnson, Charles. 1726-1728 [1999]. A General History of the Pyrates, From Their First Rise and Settlement in the Island of Providence, to the Present Time. Edited by Manuel Schonhorn. New York: Dover.

Knack, Stephen and Philip Keefer. 1997. "Does Social Capital Have an Economic Payoff?," Quarterly Journal of Economics 112: 1251-1288. 
Landa, Janet T. 1981. "A Theory of the Ethnically Homogeneous Middleman Group: An Institutional Alternative to Contract Law,” Journal of Legal Studies 10: 349-362.

. 1994. Trust, Ethnicity, and Identity: Beyond the New Institutional Economics of Ethnic Trading Networks, Contract Law, and Gift-Exchange. Ann Arbor: University of Michigan Press.

Leeson, Peter. T. 2005. “Endogenizing Fractionalization,” Journal of Institutional Economics 1: 75-98.

. 2006. "Cooperation and Conflict: Evidence on Self-Enforcing Arrangements and Heterogeneous Groups,” American Journal of Economics and Sociology 65: 891-907.

. 2007a. “An-arrgh-chy: The Law and Economics of Pirate Organization,” Journal of Political Economy 115: 1049-1094.

. 2007b. “Trading with Bandits,” Journal of Law and Economics 50: 303-321.

. 2007c. "Better Off Stateless: Somalia Before and After Government Collapse,” Journal of Comparative Economics 35: 689-710.

. 2007d. "Efficient Anarchy,” Public Choice 130: 41-53.

. 2008. “Social Distance and Self-Enforcing Exchange,” Journal of Legal Studies 37: 161188.

. 2009a. The Invisible Hook: The Hidden Economics of Pirates. Princeton: Princeton University Press.

. 2009b. "The Calculus of Piratical Consent: The Myth of the Myth of Social Contract,” Public Choice 139: 443-459.

. 2009c. “The Laws of Lawlessness,” Journal of Legal Studies 38: 471-503.

. 2010. "Rational Choice, Round Robin, and Rebellion: An Institutional Solution to the Problems of Revolution,” Journal of Economic Behavior and Organization 73: 297-307.

Leeson, Peter T. and Peter J. Boettke. 2009. “Two-Tiered Entrepreneurship and Economic Development,” International Review of Law and Economics 29: 252-259.

Leeson, Peter T., Christopher J. Coyne, and Peter J. Boettke. 2006. “Converting Social Conflict: Focal Points and the Evolution of Cooperation,” Review of Austrian Economics 19: 137147.

Leeson, Peter T. and Alex Nowrasteh. 2010. “Efficient Plunder,” mimeo. 
Leeson, Peter T. and Douglas Bruce Rogers. 2010. “Organizing Crime,” mimeo.

Leeson, Peter T. and David B. Skarbek. 2010. “Criminal Constitutions,” Global Crime 11: 279298.

Leeson, Peter T. and Edward P. Stringham. 2005. “Is Government Inevitable?,” Independent Review: 9: 543-549.

Leeson, Peter T. and Claudia R. Williamson. 2009. "Anarchy and Development: An Application of the Theory of Second Best," Law and Development Review 2: 77-96.

Milgrom, Paul, Douglass C. North, and Barry Weingast. 1990. "The Role of Institutions in the Revival of Trade: The Law Merchant, Private Judges, and the Champagne Fairs," Economics and Politics 2: 1-23.

Ostrom, Elinor. 1990. Governing the Commons: The Evolution of Institutions for Collective Action. Cambridge, UK: Cambridge University Press.

Ostrom, Elinor, Roy Gardner, and James Walker. 1994. Rules, Games, and Common-Pool Resources. Ann Arbor: University of Michigan Press.

Pospisil, Leopold. 1958. Kapauku Papuans and Their Law. New Haven: Yale University Press.

Rogozinski, Jan. 2000. Honor among Thieves: Captain Kidd, Henry Every, and the Pirate Democracy in the Indian Ocean. Mechanicsburg, PA: Stackpole Books.

Skaperdas, Stergios. 1992. "Cooperation, Conflict, and Power in the Absence of Property Rights,” American Economic Review 82: 720-739.

. 2003. "Restraining the Genuine Homo Economicus: Why the Economy Cannot be Divorced from its Governance,” Economics and Politics 15: 135-162.

Skaperdas, Stergios and Constantinos Syropoulos. 1996. "Can the Shadow of the Future Harm Cooperation?,” Journal of Economic Behavior and Organization 29: 355-372.

Skarbek, David B. 2010. "Putting the 'Con' into Constitutions: The Economics of Prison Gangs,” Journal of Law, Economics and Organization, forthcoming.

Umbeck, John. 1977. "The California Gold Rush: A Study of Emerging Property Rights,” Explorations in Economic History 14: 197-226. . 1981. "Might Makes Rights: A Theory of the Formation and Initial Distribution of Property Rights," Economic Inquiry 19: 38-59.

Woolcock, Michael. 1998. "Social Capital and Economic Development: Toward a Theoretical Synthesis and Policy Framework,” Theory and Society 27: 151-208. 
Zerbe, Richard O. and C. Leigh Anderson. 2001. "Culture and Fairness in the Development of' Institutions in the California Gold Fields," Journal of Economic History 61: 114-143. 